\author{
Ткаченко О.Б. \\ доктор технічних наук, профресор \\ кафедра безпеки, експертизи і товарознавства \\ E-mail: oksana_tkachenko@mail.ru \\ Агеєва I.M. \\ кандидат економічних наук, доцент \\ E-mail: agejeva@ukr.net \\ Беркгаут B.M. \\ магістрант \\ кафедра менеджменту та логістики \\ Одеська національна академія харчових технологій \\ вул. Канатна, 112, г. Одеса, Україна, 65039 \\ E-mail: niksaberk@gmail.com
}

\title{
ІННОВАЦІЙНІ СКЛАДОВІ СТРАТЕГІЧНОГО РОЗВИТКУ ВИНОРОБНИХ ПІДПРИЄМСТВ УКРАЇНИ
}

У статті розглянуто окремі аспекти стратегії розвитку виноробної галузі України, необхідність створення бюро з маркетингу винограду і вина України, вплив розвитку винного туризму на підвищення культури споживання вина та на розвиток виноробної галузі, розглянуто виведення на ринок України вин контрольованих найменувань за походженням (КНП).

Ключові слова: виноробна галузь, стратегічний розвиток, винний туризм, бюро з маркетингу, вина КНП, місткість ринку.

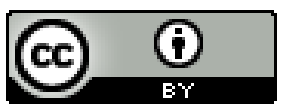

This work is licensed under a Creative Commons Attribution 4.0 International License http://creativecommons.org/licenses/by/4.0/
Постановка проблеми та їі зв'язок з важливими науковими та практичними завданнями. Сучасний стан виноградно-виноробного підкомплексу АПК характеризується як кризовий. Минулі роки реформ зумовили скорочення площ виноградників, як стабільної сировинної бази, падіння обсягів виробництва, домінування на вітчизняному ринку імпортного вина при недостатньому асортименті та низької якісті вітчизняної продукції. Тому економічне обгрунтування впливу системного стратегічного підходу на розвиток підприємств i реалізації стратегії розвитку становить особливий науковий i практичний інтерес. Тим часом виноградо-виноробна галузь i до теперішнього часу залишається недостатньо вивченою областю агропромислового комплексу.

Аналіз останніх публікацій по проблемі. Аналіз наукової та спеціальної літератури свідчить про активну науково-практичну розробку даної проблеми. В першу чергу необхідно відзначити фундаментальне дослідження світових центрів виноробства та маршрутів винного туризму X'ю Джонсона. Світові і регіональні проблеми менеджменту та маркетингу винного туризму розкриті в працях Дж. Карлстен, С. Чарстера, Рут Тейлор, С.М. Холла, Л. Шарплес, Б. Кемборна, Н. Макайоніса.

Формулювання цілей дослідження. Мета дослідження - розглянути проблеми стратегічного розвитку підприємств виноробної галузі та запропонувати інноваційні заходи щодо стратегічного розвитку підприємства.

Виклад основних результатів та їх обгрунтування. Визначаючи стратегію розвитку виноробної галузі, необхідно оцінити ємність внутрішнього українського ринку вина. Інтегральним показником розвитку внутрішнього ринку вина $є$ ємність, яка визначається обсягом виноробної продукції, що пропонується споживачам у межах ринкового простору України (розраховується як обсяг продажів національними виробниками за вирахуванням експорту і з урахуванням імпорту) (табл. 1).

Місткість ринку вина в Україні в 2011-2014 рр., в натуральному виразі, тис.дал [2]

\begin{tabular}{|l|c|c|c|c|c|}
\hline & $\mathbf{2 0 1 1}$ & $\mathbf{2 0 1 2}$ & $\mathbf{2 0 1 3}$ & $\mathbf{6}$ мic. 2013 & 6 міс. 2014 \\
\hline Виробництво, тис.дал & 23430,3 & 19543,0 & 18089,9 & 7981,2 & 4974,6 \\
\hline Імпорт, тис.дал & 5294,8 & 3706,8 & 3870,8 & 1676,0 & 1386,1 \\
\hline Експорт, тис.дал & 3349,6 & 4530,5 & 6562,9 & 3349,6 & 2432,6 \\
\hline Місткість ринку, тис.дал & 25375,5 & 18719,2 & 15397,8 & 6307,6 & 3928,1 \\
\hline Темп приросту, \% & & $-26,2 \%$ & $-17,7 \%$ & & $-37,7 \%$ \\
\hline
\end{tabular}


У європейських країнах спостерігається тенденція сталого високого рівня споживання вина i зниження обсягу споживання горілки і міцних спирт- них напоїв. В Україні така тенденція не простежується (рис. 1).

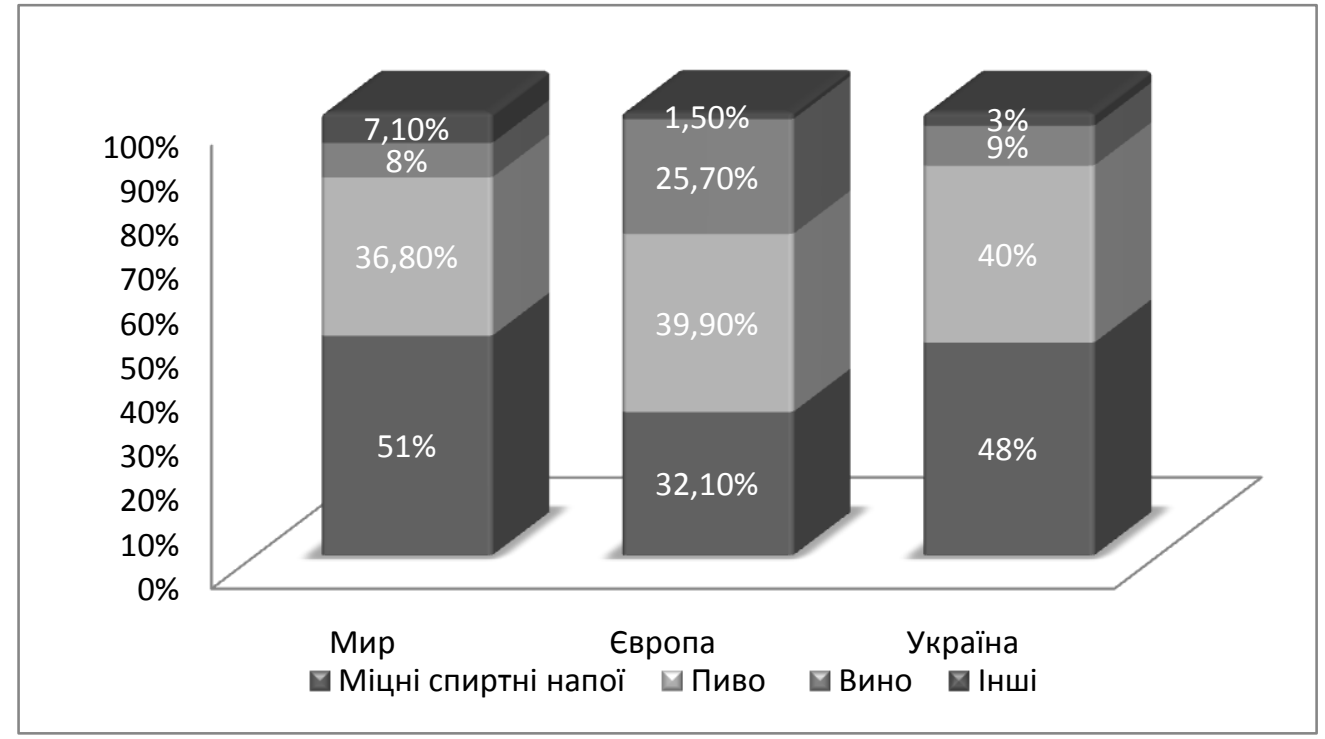

Рис. 1. Структура споживання алкогольних напоїв в країнах світу та Свропи [1]

Аналіз даних, наведених на рис. 1, свідчить, що в структурі споживання алкогольних напоїв в Україні частка вина становить усього 9,0\%. У 2015 році в Україні вироблено винопродукції 17,35 млн.дал (98\% від 2014 року) (рис.2).

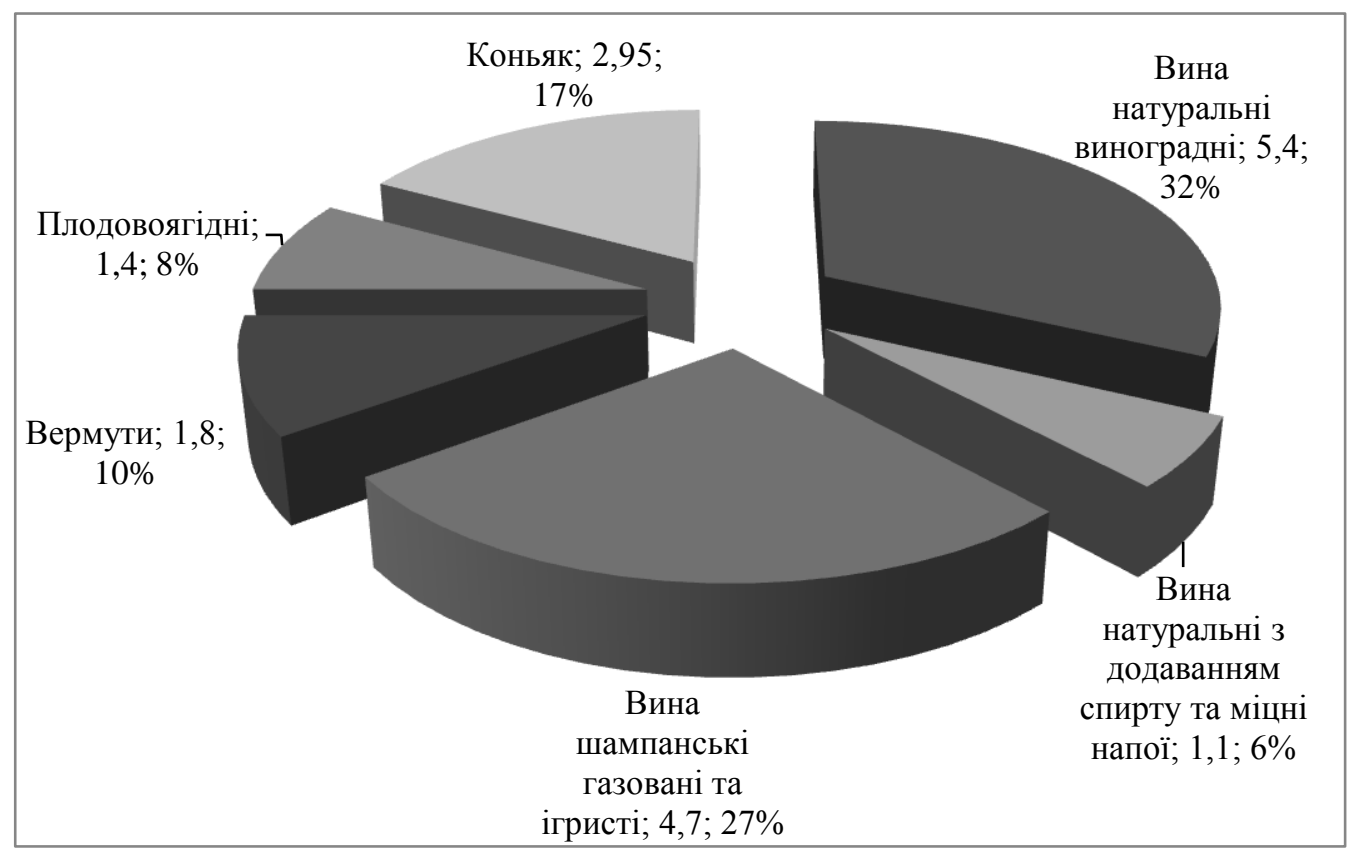

Рис. 2. Структура винопродукції у 2015 році в Україні [3]

У країнах з високим рівнем споживання вина проблеми алкоголізму незначні. У Росії, Білорусі, Україні, де віддають перевагу горілці, пияцтво й алкоголізм населення набуває загрозливих розмірів. У країнах Європейського Союзу через перевиробництво вина частину його перекурюють на спирт. У випадках, коли запаси спирту стають надмірними, пробле- му надлишків вирішують шляхом скорочення площ виноградників. При цьому власники насаджень отримують від держави компенсацію.

3 моменту вступу України до СОТ виноградарсько-виноробний підкомплекс опинився в умовах досконалої ринкової конкуренції, що призвело до обмеження державного протекціонізму національних 
виробників, до того ж більшість 3 них виявилися 3 низьким рівнем конкурентоспроможності. Через негармонізованість національних стандартів якості продукції з європейськими, неспроможність задовольнити технічні, санітарні та фіто санітарні умови для екс- порту своєї продукції національні товаровиробники фактично усунені від торгівлі на міжнародних ринках. При цьому переробка винограду та виробництво виноматеріалів в Україні суттєво знизилися у 20142015 роках ( рис.3 ).

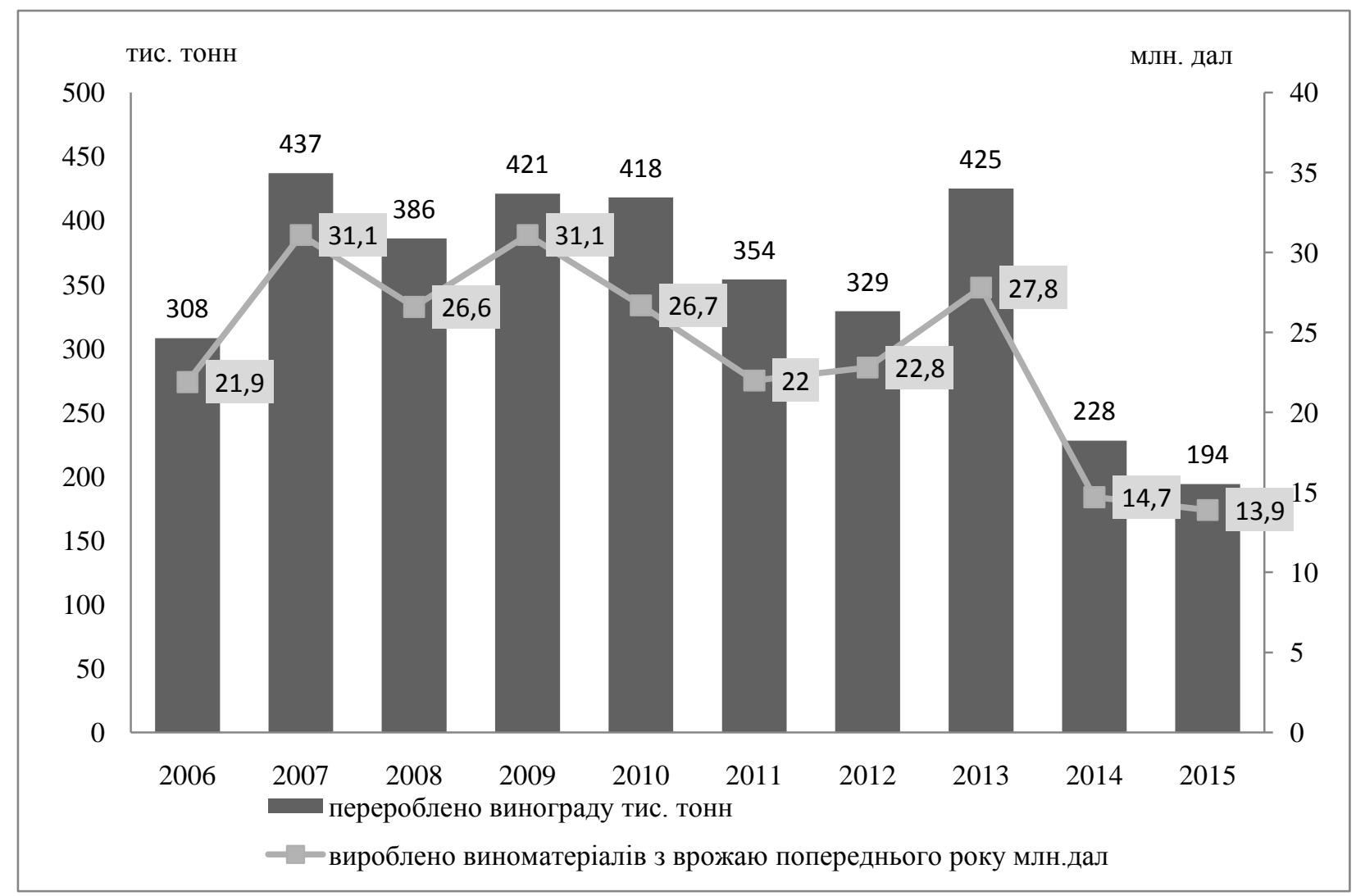

Рис.3. Динаміка переробки винограду та виробництва виноматеріалів в Україні у 2008-2015 рр. [9]

Стратегія розвитку виноградарства і виноробства України у сучасних умовах повинна бути заснована на принципах: створення умов для інтеграції економіки галузей у європейський та світовий економічний простір; створення принципово нової науково-обгрунтованої та соціально-орієнтованої інноваційної моделі структурної перебудови галузей з поетапним формуванням пріоритетів економічного, соціального й екологічного розвитку аграрного виробництва в державі [3].

Основні заходи щодо здійснення стратегічного планування на виноробних підприємствах України:

1. Проведення і впровадження системи програм щодо поліпшення якості готової продукції. Вино повинне бути натуральним, не повинно мати хвороб, пороків. Існуючі стандарти і система контролю продукції в Україні сьогодні знаходяться не на належному рівні. Наше вино поки що не відповідає рівню європейських. Мова йде про вино, яке, перш за все, виготовлене 3 винограду, вирощеного на території України.

2. Основною відмінною рисою вина повинна бути його автентичність. Крім етикетки, воно повинне володіти неповторними смаковими якостями i, щоб дегустуючи таке вино, споживач мав можливість
3 певною часткою точності визначити, 3 якої воно місцевості. Вино повинне бути самобутнім, щоб нести щось нове, неповторне вже досвідченому споживачеві.

3. Ефективний маркетинг. Слід розробляти стратегічні підходи до формування «історії» вина (розміщення на етикетці цікавої інформаційної легенди), проведення рекламних кампаній щодо інформування споживачів про культуру споживання вина, про новий вигляд і сорти за адекватною ціною в кожному ціновому сегменті.

4. Державі і бізнесу необхідно об'єднати зусилля і створити багаторічну програму підйому галузі. Ця програма покликана охопити всі рівні і структури від міністерств до міськадміністрацій, від інститутських лабораторій до ресторанів і дегустаційних залів. Для цього, необхідна підготовка сильних і професійних кадрів, які зможуть відповідально підійти до поставлених завдань і досягти своїх цілей [3].

Реалізація загальнодержавної маркетингової політики щодо отримання відповідних національному ресурсному потенціалу маркетингових позицій на світовому ринку передбачає створення в країні загальнодержавної збалансованої системи маркетингової діяльності виноградарсько-виноробної галузі, яка б 
була побудована на досвіду маркетингових, законотворчих та промоушен-організацій провідних виноробних держав світу. Систему повинна очолювати профільна організація - Бюро по маркетингу винограду і вина України, яке буде здійснювати маркетингові послуги, здійснювати промоушен українських вин 3 метою формування національного бренду «Вина України» та іміджевого позиціонування його на світовому ринку.
3 метою реалізації загальнодержавної маркетингової політики України та завоювання маркетингових позицій на світовому ринку запропонована структура загальнодержавної збалансованої системи маркетингової діяльності виноградарськовиноробного підкомплекса України, яка б була побудована згідно досвіду маркетингових, законотворчих та промоушен-організацій провідних виноробних держав світу (рис.4).

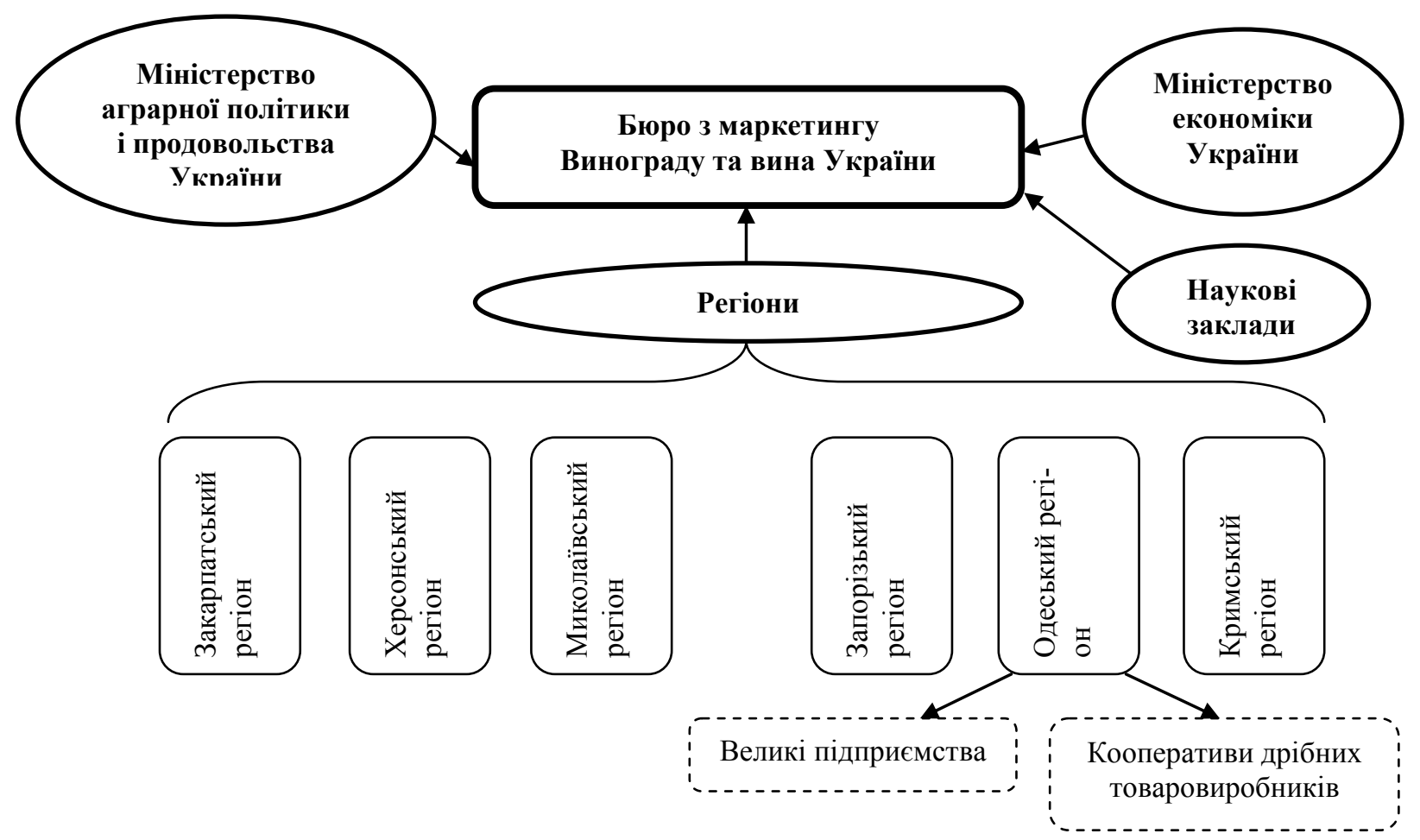

Рис.4. Структура маркетингової діяльності виноградарської галузі України [3]

Ціль Бюро - здійснювати промоушен українських вин і України, створювати маркетингові програми для відповідних внутрішніх та зовнішніх ринків винограду і вина, які включають розробку рекламних матеріалів для торгових підприємств, програм по стимулюванню збуту продукції, підготовку іміджевих програм та матеріалів, пропозицій для зв'язку виноградарів та виноробів з громадською спільнотою. Однім 3 головних завдань Бюро повинне бути завдання формування національного бренду «Вина України» та іміджеве позиціонування його на світовому ринку. Для цього Бюро повинно проводити цілу низку міжнародних масштабних заходів: міжнародні винні фестивалі, конкурси-дегустації, свята молодих українських вин, різні гастрономічні фестивалі, завдяки яким вітчизняні виноградарі та винороби мають можливість отримати міжнародне визнання та популярність. Одним з діючих напрямків популяризації українського винограду і вина є винний туризм.

В умовах реформування виноградарства та виноробства України особливу увагу слід приділяти до сфери реалізації та стимулювання збуту продукції, розвитку агромаркетингу, винного туризму, що дозволяє більш повно задовольняти потреби споживачів у виноградарсько-виноробній продукції та підвищувати конкурентоспроможність іiі товаровиробників на внутрішньому та світовому ринках.

Вина КНП - це аналог французьких вин контрольованих за місцем походження, і що часто вони $\epsilon$ Великими Винами. Але не всі знають, що в Україні тільки компанія ТОВ ПТК «Шабо» має право і має технологічні можливості створювати такі вина. У Великих винах втілені кращі риси терруара - це те неповторне поєднання природно-кліматичних факторів місцевості, які сприятливо впливають на якість і характер вина. Грунти місцевості Шабо - унікальні. Їх вивчення почалося ще в 19 столітті - у часи швейцарських переселенців, що заклали на цій землі основи культурного виноробства. Зараз ми знаємо, що в терруари місцевості Шабо 7 підтипів грунту. Під землею виноградна лоза галузиться так само, як і над землею. Коріння постійно шукають собі їжу і вологу в світі мінералів: тут - південноукраїнський чорнозем, там супіщані землі (піски), тут - суглинні грунту. У місцевості Шабо виявлені видатні, рідкісні суглинисті грунти з вапняком ці «високоцінні ділянки терруара» так звані землі grandcru. Всього ж в компанії ТОВ ПТК «Шабо» - більше 20 сортів винограду, які спеці- 
ально для терруара були підібрані в Європі. Цим лозам вже більше 10 років - оптимальний вік для отримання Великих Вин. $€$ такий вислів: «Лоза страждає - вино радіє!». Тому виноградарі висаджують між рядами траву, щоб поліпшити структуру грунту i стимулювати кореневу систему. Завдяки цьому коренева система розвивається активніше, просуваючись до 15 метрів вглиб землі в пошуках вологи і мікроелементів для повноцінного харчування. Також регулюють навантаження на виноградній лозі, іншими словами - зменшують врожайність, обриваючи зайві виноградні грона. Структура розподілу вин КНП у країнах Європи показує на їх суттєву частку саме у Франції і Італії ( рис. 5 ).

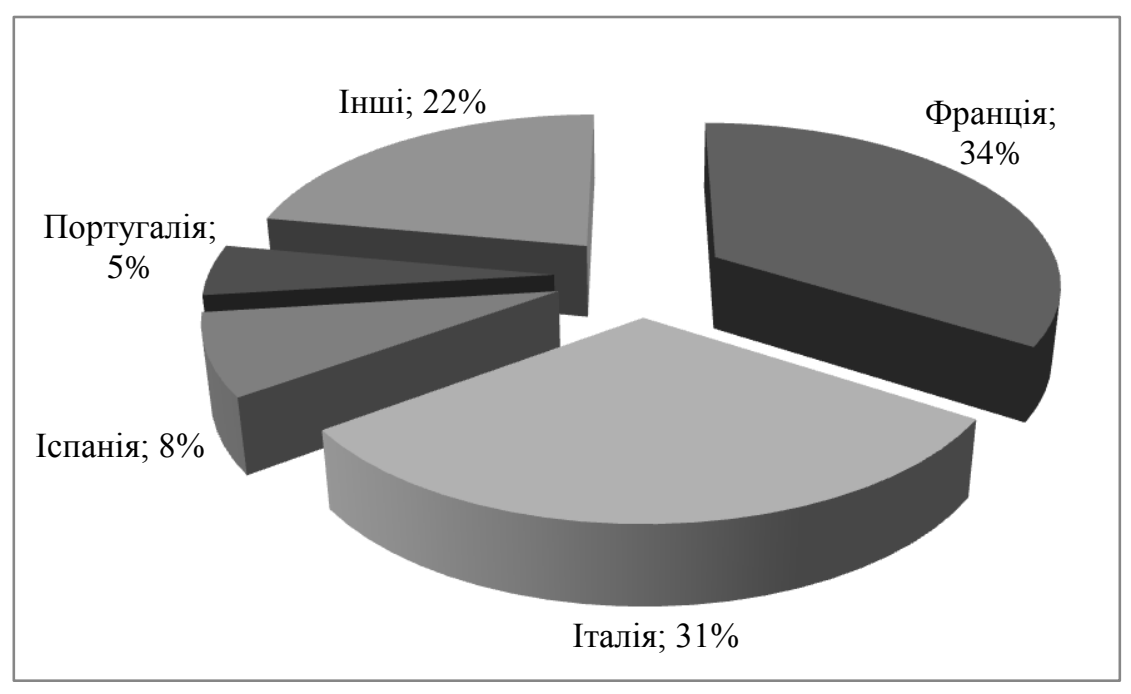

Рис.5. Вина КНП у свропейських країнах [10]

На основі проведеного SWOT аналізу та в рамках розробки стратегії концентрації, як основи стратегічного набору підприємства було розроблено рекламну компанію для виведення на ринок нового виду продукції - колекцій Grande Reserve. Це вина преміум-класу, які відповідають найвищому міжнародному статусу Великих Вин. Це лімітована колекція вин, яка складається $з 9$ найменувань, за сезон буде вироблено всього лише 100 - 300 пляшок кожного найменування. Рекламна компанія складається 3 таких заходів: участь у виставках, реклама у пресі, реклама на радіо.

Точка нульової ефективності менша за планований обсягу виробництва (складає 247 пляшок, при запланованих 500 пляшок в перший рік). Тому можна зробити висновок, що проведення рекламної кампанії є ефективним заходом.

В рамках розробки стратегії диверсифікаційного росту підприємства запропоновано новий напрямок розвитку - винний туризм та прорахована економічна ефективність відкриття філіалу «Центру культури вина» в м.Одеса. За повідомленнями світових інформаційних агентств, популярність винного туризму продовжує зростати: прибутковість цього бізнесу оцінюють приблизно в 2,5 млрд. євро на рік. Лише в Італії налічується приблизно 5 млн. активних винних туристів і 140 спеціалізованих винних маршрутів для енологів і гурманів. Експерти вважають, що винний туризм використовує тільки $20 \%$ потенціалу і може легко подвоїти обороти в найближчому майбутньому. Хоча основним об'єктом уваги виступає вино, туристи активно дегустують страви національної кухні і гастрономію місцевого виробництва а сьогодні у всіх виноробних регіонах світу вважають за доцільне розвивати і підтримувати цей вид тематичного туризму, відповідно, рекламувати продукцію місцевих виробників алкогольних напоїв і просувати місцевий туристичний продукт, отримуючи додаткові економічні та соціальні вигоди від туристів - цінителів вина. Це стосується в першу чергу відомих євро- пейських виноробних регіонів Італії, Франції, Іспанії, Португалії, Угорщини, а також країн «нового світу вина», таких як Австралія, Аргентина, Чилі, США і Південна Африка, де винний туризм відіграє важливу роль у популяризації місцевої виноробної продукції.

Розвиток спеціалізованих послуг такого виду туризму дозволяє збільшити тривалість туристичного сезону в регіоні, підвищити туристичний імідж місцевості, збільшити кількість туристичних прибуттів, збагатити і диференціювати місцевий туристичний продукт за рахунок впровадження винних турів, фестивалів, екскурсій, дегустації та презентацій [4].

Висновки та перспективи подальших досліджень. Отже, винний туризм порівняно нове явище на ринку туристичних послуг України. Перспективи його розвитку в Україні, на нашу думку, повинні бути зосереджені на таких напрямках:

- розробка програм сталого розвитку регіонів, державна і муніципальна підтримка заходів щодо створення сприятливого організаційно-правового клімату для розвитку туризму, створення регіональних і національних винних і гастрономічних маршрутів, в рамках яких повинно бути передбачено відкриття спеціалізованих туристичних об'єктів - етноресторанів, дегустаційних залів, музеїв гастрономії, етнічних селищ і містечок, а також тематичних заходів які будуть сприяти створенню конкурентоспроможного місцевого туристичного продукту, підвищенню туристичної привабливості регіону. Ця робота повинна поєднуватися 3 нормативно-правової та інституційної підтримкою розвитку вітчизняного виноробства в умовах глобальної конкуренції на європейському та світовому ринках продуктів і напоїв з урахуванням правил СОТ, норм і охоронних вимог до якості продукції;

- вивчення міжнародного досвіду розвитку винного туризму, співпраця 3 кращими виробниками Італії, Іспанії, Франції, Швейцарії в галузі виноробної харчової та переробної промисловості, впровадження 
екологічно чистих технологій, а також використання тимчасового маркетингового комплексу просування продукції та брендингу продукції окремих центрів виноробства і виноробних регіонів;

- реклама винних турів по Україні з метою збільшення внутрішніх і міжнародних туристичних потоків підвищення культури споживання вина, ознайомлення 3 якісною натуральною продукцією місце- вих виробників. Для популяризації національних гастрономічних традиції за підтримки державних органів і про професійних об'єднань планується національний проект «Українські винні шляхи» 3 метою висвітлення багатого і різноманітного асортименту вин та інших алкогольних напоїв, ознайомлення з історико-культурною спадщиною українського виноробства $[4]$.

\section{Література}

1. Осипов В. Виноградарство та виноробство України. Сучасний стан, проблеми, тенденції розвитку / В.Осипов, Л. Осипова // Економіст. - 2015. - № 5. - С. 28-31

2. Державна служба статистики [Електронний ресурс]. - Режим доступу: http://www.ukrstat.gov.ua/.

3. Белоус І.В. Стратегія розвитку виноградарства і виноробства України та передумови виходу їх продукції на світовий ринок : автореф. дис. канд. ек. наук : спец. 08.00 .03 - «Економіка та управління національним господарством» [Електронний ресурс]. - Режим доступу : http://www.mnau.edu.ua/files/18_02_02/preprint-belousi-v-2014-11-14.pdf.

4. Басюк Д.И. Социально-экономические условия развития винного туризма в Украине / Д.И Басюк / Напитки. Технологии и инновации. - 2014. - №10. - С.26-30

5. Kotler N. Museum Marketing and Strategy: Designing Missions, Building Audiences, Generating Revenue and Resources / N. Kotler, P. Kotler, W. I. Kotler, 2008. - 544 p.

6. Aaker David A. Strategic Market Management. Wiley, 2013. - 336 p.

7. Henry Mintzberg, Joseph B. Lampel, James Brian Quinn, Sumantra Ghoshal The Strategy Process: Concepts, Context, Cases. Prentice Hall,2002. - 489 p.

8. Вино [Електронний ресурс]. - Режим доступу:

http://comcon.com.ua/ru/sektory_rynkov/alkogolnye_napitki_i_tabak/vino/profiletrends_short_vino.htm ProfileTrends Short.

9. Вино [Електронний ресурс]. - Режим доступу:

http://comcon.com.ua/ru/sektory_rynkov/alkogolnye_napitki_i_tabak/vino/markettrends_vino.htm MarketT

10. Вино [Електронний ресурс]. - Режим доступу:

http://comcon.com.ua/ru/sektory_rynkov/alkogolnye_napitki_i_tabak/vino/brandtrends_vino.htm BrandTrends.

11. Обзор рынка алкогольных напитков [Електронний ресурс]. - Режим доступу:

http://rb.com.ua/rus/marketing/tendency/8889/

Стаття надійшла 22.02.2016 Стаття прийнята до друку 09.03.2016

Ткаченко О.Б.

доктор технических наук, профессор

кафредра безопасности, экспертизы и товароведения

E-mail: oksana_tkachenko@mail.ru

Агеева И.Н.

кандидат экономических наук, доцент

E-mail: agejeva@ukr.net

Беркгаут B.M.

магистрант

кафедра менеджмента и логистики

Одесская национальная академия пищевых технологий

ул. Канатная, 112, г. Одесса, Украина, 65039

E-mail: niksaberk@gmail.com

\section{ИННОВАЦИОННЫЕ СОСТАВЛЯЮЩИЕ СТРАТЕГИЧЕСКОГО РАЗВИТИЯ ВИНОДЕЛЬЧЕСКИХ ПРЕДПРИЯТИЙ УКРАИНЫ}

\footnotetext{
В статье рассмотрены инновационные аспекты стратегии развития винодельческой отрасли Украины, необходимость создания Бюро по маркетингу винограда и вина Украины, влияние развития винного туризма на повышение культуры потребления вина и на развитие винодельческой отрасли, рассмотрено выведение на рынок Украины вин контролируемых наименований по происхождению (КНП).

Современное состояние виноградно-винодельного подкомплекса АПК характеризуется как кризисное: сокращение площадей виноградников, как стабильной сырьевой базы, падение объемов производства, доминирование на отечественном рынке импортного вина, при недостаточном ассортименте и низком качестве отечественной продукции. Поэтому системный стратегический подход к развитию предприятий и реализации стратегии развития составляет особенный научный и практический интерес. Стратегия развития виноградарства и виноделия Украины в современных условиях должна быть основана на принципах: создание условий для интеграции экономики отраслей в европейское и мировое экономическое пространство; создание принципиально новой научно обоснованной и социально ориентированной инновационной модели структурной перестройки отраслей с поэтапным формированием приоритетов экономического, социального и экологического развития аграрного производства в государстве.
} 
В условиях реформирования виноградарства и виноделия Украины особенное внимание следует уделять сфере реализации и стимулирования сбыта продукции, развития агромаркетинга, винного туризма, что позволяет повышать конкурентоспособность виноградарско-винодельной продукции на внутреннем и мировом рынках.

Ключевые слова: винодельная отрасль, стратегическое развитие, винный туризм, бюро маркетинга, вина КНП, емкость рынка.

Tkachenko O.

Doctor of Technical Sciences, Professor

Department of Safety, Expertise and Merchandizing

E-mail: oksana tkachenko@mail.ru

Agēieva I.

Ph.D. in Economics, Associate Professor

E-mail: agejeva@ukr.net

Berkgaut V.

undergraduate

Department of Management and Logistics

Odessa National Academy of Food Technologies

Kanatna str., 112, Odessa, Ukraine, 65039

E-mail: niksaberk@gmail.com

\section{THE INNOVATIVE COMPONENTS OF STRATEGIC DEVELOPMENT OF THE WINE-MAKING ENTERPRISES OF UKRAINE}

In article innovative aspects of strategy of development of wine-making branch of Ukraine, need of creation of Bureau on marketing of arapes and wine of Ukraine, development influence are considered wine tourism on increase of culture of consumption of wine and on development of wine-making branch, removal on the market of Ukraine of wines of controlled names bv oriain is considered (KNP).

The current state grape winemaking a subcomplex of aqrarian and industrial complex is characterized as crisis: reduction of the areas of vinevards, as stable source of raw materials, declinina production. domination in the domestic market of import wine, at the insufficient range and poor qualitv of a domestic production. Therefore system strategic approach to development of the enterprises and realization of strategy of development makes special scientific and practical interest.

Strateav of development of wine arowing and winemaking of Ukraine in modern conditions has to be based on the principles: creation of conditions for intearation of economv of branches into the European and world economic space; creation of essentially new evidence-based and socially oriented innovative model of restructuring of branches with stage-by-stage formation of priorities of economic, social and ecological development of aqrarian production in the state.

In the conditions of reforming of wine growing and winemaking of Ukraine the special attention should be paid to the sphere of realization and sales promotion of production, development of aqromarketing, wine tourism that allows to increase competitiveness of vinogradarsko-vinodelny production in the internal and world markets.

Kevwords: wine industry, wine tourism,strategic development, bureau of marketing,wine CNR, market capacity.

\section{References}

1. Osypov, V., \& Osypova, L. (2015). Vynohradarstvo ta vynorobstvo Ukrainy. Suchasnyi stan, problemy, tendentsii rozvytku. Ekonomist, 5, 28-31.

2. Derzhavna sluzhba statystyky. (2015, October). Retrieved from http://www.ukrstat.gov.ua/

3. Belous, I. V. (2015, December). Stratehiia rozvytku vynohradarstva i vynorobstva Ukrainy ta peredumovy vykhodu yikh produktsii na svitovyi rynok. Retrieved from http://www.mnau.edu.ua/files/18_02_02/preprint-belous-iv-2014-11-14.pdf

4. Basiuk, D. Y. (2014). Sotsyalno-ekonomycheskye uslovyia razvytyia vynnoho turyzma v Ukrayne. Napytky. Tekhnolohyy Y Ynnovatsyy, 10, 26-30.

5. Kotler, N., Kotler, P., \& Kotler, W. I. (2008). Museum Marketing and Strategy: Designing Missions, Building Audiences, Generating Revenue and Resources.

6. Aaker, D. A. (2013). Strategic Market Management. Wiley.

7. intzberg, H., Lampel, J. B., Quinn, J. B., \& Ghoshal, S. (2002). The Strategy Process: Concepts, Context, Cases. Prentice Hall.

8. Vyno. (2016, February). Retrieved from

http://comcon.com.ua/ru/sektory_rynkov/alkogolnye_napitki_i_tabak/vino/profiletrends_short_vino.htm ProfileTrends Short

9. Vyno. (2016, January). Retrieved from

http://comcon.com.ua/ru/sektory_rynkov/alkogolnye_napitki_i_tabak/vino/markettrends_vino.htm MarketT

10. Vyno. (2016, January). Retrieved from

http://comcon.com.ua/ru/sektory_rynkov/alkogolnye_napitki_i_tabak/vino/brandtrends__vino.htm BrandTrends.

11. Obzor runka alkoholnukh napytkov. (2016, January). Retrieved from

http://rb.com.ua/rus/marketing/tendency/8889/ 